\title{
Solar radiation distribution inside a monospan greenhouse with the roof entirely covered by photovoltaic panels
}

\author{
Sergio Castellano, ${ }^{1}$ Pietro Santamaria, ${ }^{2}$ Francesco Serio ${ }^{3}$ \\ ${ }^{1}$ Department of Science of Agriculture, Food and Environment, University of Foggia; \\ ${ }^{2}$ Department of Agricultural and Environmental Science, University of Bari; ${ }^{3}$ Institute \\ of Sciences of Food Production, National Research Council, Bari, Italy
}

\begin{abstract}
In the present work the variation over space and time of the amount of the photosynthetic photons flux density, inside a greenhouse entirely covered with photovoltaic panels was investigated experimentally and numerically. The greenhouse had $10.00 \mathrm{~m}$ spam width, $50.00 \mathrm{~m}$ length, $3.00 \mathrm{~m}$ height of the gutter, $6.60 \mathrm{~m}$ height of the edge. Data were acquired in the period $18^{\text {th }}$ April- $8^{\text {th }}$ June 2014 by one sensor outside and one inside the experimental greenhouse built in Southern Italy. Numeric simulations were performed by means of commercial software Autodesk ${ }^{\circledR}$ Ecotect $^{\circledR}$. For the investigated greenhouse model, the exposed percentage - the ratio of the calculated insolation at a particular point within an enclosure to the simultaneous unobstructed outdoor insolation under the same sky conditions - was calculated over a three dimensional grid formed by $50 \times 10 \times 15$ cells each with $1.00 \times 1.00 \times 0.20 \mathrm{~m}$ size. The long-term analysis demonstrated a good capability of the numerical model to predict the shading effect inside a photovoltaic greenhouse combining the daily calculated exposed percentage with measurements of solar radiation. The model was able also to predict the qualitative behaviour of the variation of photons flux during the day even if the measured values showed a higher fluctuation of values.
\end{abstract}

Correspondence: Sergio Castellano, Department of Science of Agriculture, Food and Environment (SAFE), University of Foggia, via Napoli 25, 71100 Foggia, Italy.

E-mail: sergio.castellano@unifg.it

Key words: Photovoltaic greenhouse; radiometric performance; shading effect.

Acknowledgements: this research was supported by the Italian Ministry of Agricultural and Forestry Policies within the Research project Improvement of plant production performance with soilless systems under greenhouse covered with semi-transparent photovoltaic modules(Hortisolar). We thank Dr. Pierpaolo Cosma for technical assistance.

Received for publication: 16 June 2015.

Accepted for publication: 27 August 2015.

CC Copyright S. Castellano et al., 2016

Licensee PAGEPress, Italy

Journal of Agricultural Engineering 2016; XLVII:485

doi:10.4081/jae.2016.485

This article is distributed under the terms of the Creative Commons Attribution Noncommercial License (by-nc 4.0) which permits any noncommercial use, distribution, and reproduction in any medium, provided the original author(s) and source are credited.

\section{Introduction}

Solar photovoltaic (PV) installations are quickly increasing in Europe and in Italy during the last ten years. The energetic production from PV panels increased in Europe from almost $1 \mathrm{GW}$ in 2004 to 88 GW in 2013, in the same period in Italy it passed from almost 0.1 to 18.0 GW (EPIA, 2014). The rapid expansion of the PV sector - and more in general of the renewable sources sector - is mainly due to the advantageous remuneration policies available in various Countries (Badcock \& Lenzen, 2010; Sarasa-Maestro et al., 2013).

In rural landscapes, due to the land consumption and to the environmental impacts involved by ground-mounted PV plants (Beylot et al., 2011; Taylor, 2014), government remuneration polices promoted the realisation of integrated PV systems with the structures instead of ground-mounted PV plants (GSE, 2013).

In this context, greenhouses covered with PV modules have been developed during last years (Cossu et al., 2014). In 2012 almost the $6 \%$ of energy produced by PV panels in Italy (16420 MW) was obtained by plants placed on greenhouses and shelters (GSE, 2013). The main challenge for these mixed systems is to gain higher productiveness with respect to the quality and to obtain a lower impact on environment than both systems implemented in an independent area (Poncet et al., 2012). On the one hand the placement of PV modules on greenhouses takes advantage from the large surface available and avoids the heavy debate on the land use because, unlike the ground-mounted systems, it does not subtract area for the cultivation of agricultural products for very long periods (almost thirty years) and it does not compromise the soil fertility (Tudisca et al., 2013). Moreover, during summer period - especially in Mediterranean region - shading systems are required and cultivations are suspended (Marucci et al., 2013). On the other hand, the opaque PV modules intercept the solar radiation necessary for crop production, in contrast with the main purpose of a greenhouse: to optimise solar radiation transmission under controlled conditions in order to improve the growing environment (British Standards Institution, 2001; Vox et al., 2010). It is strategic to find a balance between the two opposite needs: to reduce the shading effect of PV panels in order to allow as much as possible the photosynthetically active radiation (PAR) component entering into the greenhouse (Schettini et al., 2011) and to improve the energy production which is proportional to the opaque surface of the panels (Vox et al., 2008). At this aim, three technological research areas are involved (Poncet et al., 2012): the greenhouse design optimisation including photovoltaic panels (Al-Ibrahim et al., 2006; Yano et al., 2009; Sonneveld et al., 2010; Yano et al., 2010; Wenger and Teitel, 2012); the development of more transparent solar panels (Biancardo et al., 2007; Yano et al., 2014); and/or organic photovoltaic materials (Emmot et al., 2015) the selection of species adapted to this particular system of production (Kadowaki et al., 2012; Lopez et al., 2012; Urena Sanchez et al., 2012; Klaring and Krumbein, 2013). 
The geometry of the greenhouse, the PV panels distribution on roof, and the building site location strongly affect the amount of PAR radiation falling inside the greenhouse (Gupta et al., 2012) with high fluctuation of photon flux in different zones during the day (Castellano, 2014; Cossu et al., 2014).

Actually, in order to interdict the building of greenhouses with an amount of opaque panels on covering not coherent with the plant production, local laws assign a threshold value- usually the $25-50 \%$ of the projection on the soil of the roof (Tudisca et al., 2013; Cossu et al., 2014). These ranges, aimed to avoid financial speculations, seem not to be based on scientific results concerning the agricultural performances required to the PV greenhouse but only on empirical assessments. The study of the greenhouse climate conditions - especially with regard to the spatial distribution- is crucial for choosing the best combination of solar panels and crops, in order to optimise both the energy and crop production (Bojacá et al., 2009; Dupraz et al., 2011; LopezMarin et al., 2012; Urena-Sanchez, 2012) having into account the agronomic requirements in terms of PAR (Gaastra, 1959). At this aim in the present work the variation of the amount of PAR, over space and time, in terms of photons flux density, inside a PV greenhouse was investigated experimentally and numerically.

\section{Materials and methods}

\section{Experimental setup}

A mono-pitched steel photovoltaic greenhouses (PVG), E-W oriented, was built in Avetrana (Taranto) in Southern Italy $\left(40^{\circ} 20^{\prime} 04^{\prime \prime} \mathrm{N}\right.$, $\left.17^{\circ} 44^{\prime 2} 25^{\prime} \mathrm{E}\right)$. The greenhouse had $10.00 \mathrm{~m}$ spam width, $50.00 \mathrm{~m}$ length, $3.00 \mathrm{~m}$ height of the gutter, $6.60 \mathrm{~m}$ height of the edge and consequently the slope of the roof was almost $30^{\circ}$ (Figure 1). The roof was south exposed and its slope optimised the efficiency of PV panels production at this latitude.

The roof was entirely covered with PV polycrystalline, model SOLSONICA 610 [Solsonica S.p.A., Cittaducale (RI), Italy]. Eastern and northern gable walls were covered with polyvinyl chloride (PVC) sheets. Sidewalls were covered by polyethylene film, in the bottom part a low PVC panel of $1.00 \mathrm{~m}$ height extended at both sides of the greenhouse along its length. Openings were provided on sidewalls (Figure 2). The photon flux density (PFD in $\mu \mathrm{mol} \mathrm{m}{ }^{-2} \mathrm{~s}^{-1}$ ) in the PAR range was measured by means of two Quantum Sensors LICOR LI-190SA (LI-COR, Inc., Lincoln, NE, USA). One sensor $\left(S_{\text {out }}\right)$ was placed outside on the gutter of PVG and one $\left(S_{\text {in }}\right)$ inside PVG at $1.60 \mathrm{~m}$ from the ground next to the northern sidewall, $S_{\text {in }}$ was placed on the power panel (Figures 1 and 2).

PFD measured respectively outside and inside the PVG was indicated as $\mathrm{PFD}_{\text {out }}$ and $\mathrm{PFD}_{\mathrm{ms} \text {-in. }}$.

Data, recorded each half hour with an acquisition time of $30 \mathrm{~s}$, were gathered from the $18^{\text {th }}$ April 2014 (day of the year 108) to the $8^{\text {th }}$ June 2014 (day of the year 159).

In order to calibrate measurements of the sensors, data concerning daily sun radiation (DSR) and duration of sunlight in a day $\left(\mathrm{H}_{\mathrm{s}}\right)$, expresses in hours $(\mathrm{h})$, gathered at the nearby Meteorological Station of the Airport of Grottaglie - almost $33 \mathrm{~km}$ far from Avetrana -, were acquired. DSR $\left(\mathrm{J} \mathrm{m}^{-2}\right)$ is the daily total amount of solar radiation falling upon a horizontal surface of one square meter area, hourly data were not available.

\section{Numerical method}

Commercial software Autodesk® Ecotect ${ }^{\circledR}$ Analysis (Autodesk, 2011; Ecotect, 2014) was used to simulate the insolation inside the model of PVG. Insolation is the amount of incident solar radiation that falls upon a surface. In this study data were gathered, in the PVG model, on a three-dimensional grid formed by $50 \times 9 \times 15$ cells each with $1.00 \times 1.10 \times 0.20$ size. Insolation is calculated in joule per square meter $\left(\mathrm{J} \mathrm{m}^{-2}\right)$ and refers to the wide spectrum radiant energy from the sun, which strikes an object or surface within the Ecotect ${ }^{\circledR}$ model. This includes both a direct component from the sun itself (sunshine) and a diffuse component from the visible sky (skylight). All components are calculated directly from the geometry of the model as well as from hourly direct and diffuse solar radiation. Ecotect ${ }^{\circledR}$ analysis are based on databases, associated to the site, named weather data file containing hourly data for both diffuse and direct solar radiation as well as temperature, wind speed and direction, relative humidity and rainfall. External shading in Ecotect ${ }^{\circledR}$ is calculated using shading masks. A shading mask stores the percentage in shade of any surface at a range of sky angles. The mask is used in the calculation of both diffuse and beam components (direct). For the beam component, the position of the sun is first calculated at the required date and time. This gives the sun position in the sky expressed by azimuth and altitude which can be used to locate a specific cell in the mask which stores the percentage of the object that is in shade from that angle. From this shading percentage an exposure value is calculated from, which is then multiplied by the beam component. As the distribution of diffuse light over the sky dome can vary very quickly as clouds gather and disperse, it is not possible to accurately model over any period exactly where in the sky the majority of radiation is coming from - thus Ecotect ${ }^{\circledR}$ assumes a uniform distribution of diffuse radiant energy. Thus, to calculate the diffuse factor, the area-weighted (or in this case solid angle) exposure value over the entire sky dome is used (Autodesk, 2011). The weather data file of

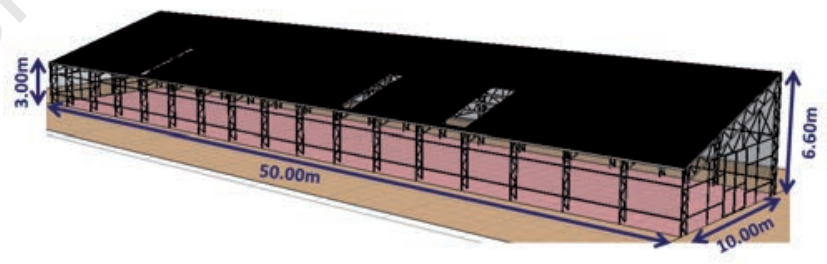

Figure 1. 3D model of the tested photovoltaic greenhouse.

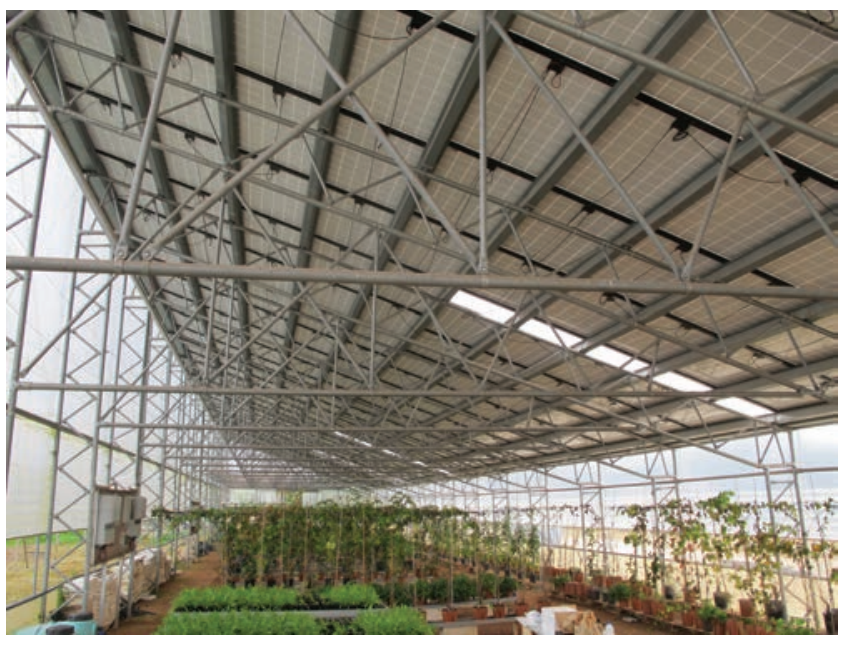

Figure 2. Tested photovoltaic greenhouse at experimental field of Avetrana (Taranto), internal view from Western gable wall. 
Avetrana was downloaded by the U.S. Department of Energy (2015).

The radiometric characteristics of the materials are managed by the software in terms of visible transmittance and reflectivity. The radiometric properties of covering materials and the internal surface of PV panels were calculated by means of a Spectroradiometer Perkin Helmer of the University of Bari (Table 1). For the investigated greenhouse model, the exposed percentage $\left(\mathrm{EP}_{\mathrm{c}}\right)$ was calculated for the period $18^{\text {th }}$ April- $8^{\text {th }}$ June 2014 , from 8.00 a.m to 04.00 p.m. $\mathrm{EP}_{\mathrm{c}}$ is defined as the ratio of the calculated insolation at a particular point within an enclosure to the simultaneous unobstructed outdoor insolation under the same sky conditions, expressed as a percentage. The exposed percentage calculated in the model at the same position of the sensor $S_{\text {in }}$, was indicated as $\mathrm{EP}_{\mathrm{c} \text {-in. }}$ Commercial software R 3.1.3. (Hornik, 2015) was used in order to evaluate the Pearson's correlation factor, $R$, when two series of data were compared. The significance of the correlation was evaluated by means of T-test, the statistical significance was attained when P-value was less than the significance level set to 0.05 (5\%).

\section{Results and discussion}

In Figure 3 the variation of measured $\left(\mathrm{EP}_{\mathrm{m}-\mathrm{in}}\right)$ and calculated $\left(\mathrm{EP}_{\mathrm{cS} \text {-in }}\right)$ average daily values of the $\mathrm{EP}$ during the investigated period is shown. Calculated values were affected by the geometry of the photovoltaic greenhouse and sun position deriving from the local weather file and were almost regular along the whole investigated period, high fluctuation of measured values depended on real weather conditions. The average value of calculated EP (1.54\%) was lower than the meas-

Table 1. Radiometric properties of covering materials: transmissivity $(T)$ and reflectivity $(\rho)$.

\begin{tabular}{lcc} 
Material & $\mathrm{T}$ & $\rho$ \\
$\mathrm{PE}$ & 0.89 & 0.05 \\
$\mathrm{PVC}$ & 0.84 & 0.07 \\
\hline PV panel (internal surface) & - & 0.43
\end{tabular}

$\mathrm{PE}$, polyethylene; $\mathrm{PVC}$, polyvinyl chloride; $\mathrm{PV}$, photovoltaic.

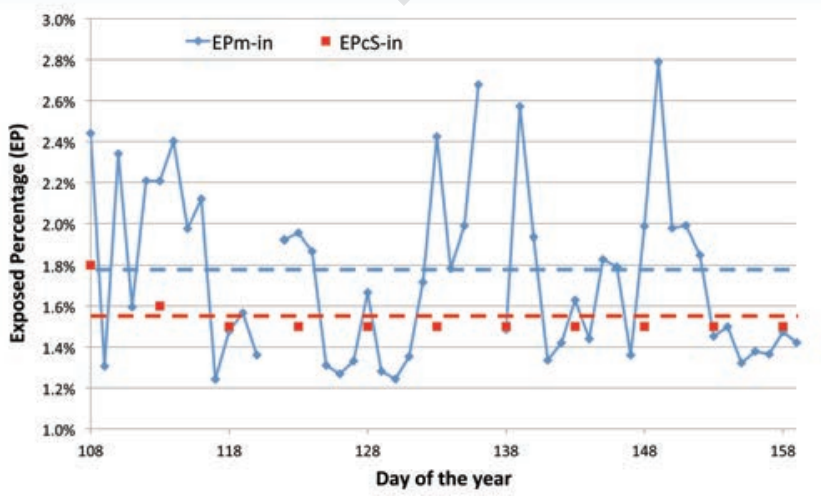

Figure 3. Daily average values of calculated $\left(\mathrm{EP}_{\mathrm{cS}-\mathrm{in}}\right)$ and measured $\left(\mathrm{EP}_{\mathrm{m} \text {-in }}\right)$ exposed percentage inside the photovoltaic greenhouse. Markers indicate calculated (red) and measured (blue) data, the dashed lines indicate the average values along the entire period. ured one (1.79\%). In field conditions, the correlation between EP and external PFD was negative $(\mathrm{R}=-0.86 \mathrm{P}=0.029)$ as highlighted in Figure 4A. EP was higher when the PFD was lower when presumably the sky was cloudy and namely the diffuse component was predominant. Moreover, results depended on different weather conditions due to the different transmissivity of plastic transparent coverings with respect to direct (clear sky) and diffuse (cloudy) light (Schettini et al., 2011).

In order to verify the operating of outside sensor $\mathrm{S}_{\text {out }}$, the measured outside photon flux density ( $\mathrm{PFD}_{\text {out }}$ ) and $\mathrm{DSR}$ were compared (Figure $4 \mathrm{~B}$ ). Two series were expressed in different units- the PFD in $\mu \mathrm{mol} \mathrm{m}{ }^{-2} \mathrm{~s}^{-1}$ and the DSR in MJ $10^{-2} \mathrm{~m}^{-2}$ - and were not directly correlated. Figure 4 shows a very good correlation between two data $(\mathrm{R}=0.79, \mathrm{P}<0.01)$ especially in the intermediate period from the $129^{\text {th }}$ to the $147^{\text {th }}$ day of the year. Higher differences, probably due to the different site acquisition of data, were highlighted in days 110, 115, 119 and into the interval 149-155 (Figure 4).

Multiplying the daily average calculated value of exposed percentage at the position of the sensor inside the greenhouse $\left(\mathrm{EP}_{c \mathrm{~s} \text {-in }}\right)$ for the measured outside photon flux density ( $\mathrm{PFD}_{\text {out }}$ ) it was possible to rate the flow of photons theoretically falling in the model:
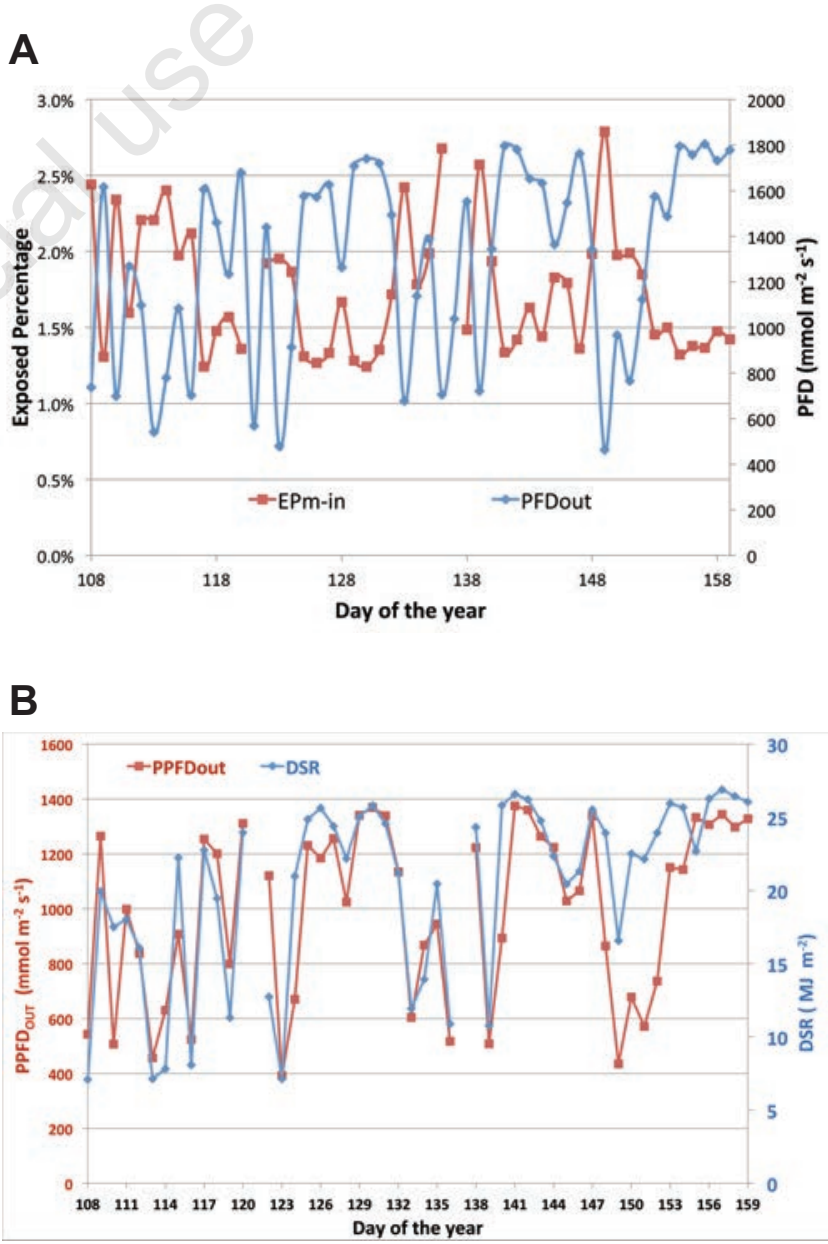

Figure 4. A) Comparison between the daily average values of exposed percentage $\left(\mathrm{EP}_{\mathrm{m} \text {-in }}\right)$ and photon flux density measured outside the photovoltaic greenhouse $\left(\mathrm{PFD}_{\text {out }}\right)$; $\left.\mathrm{B}\right)$ Daily sun radiation (DSR) and daily variation of the average value of the measured outside photon flux density $\left(\mathbf{P F D}_{\text {out }}\right)$ during the investigated period. 


$$
P F D_{c S-\text { in }}=P F D_{\text {oUT }} E P_{c S-\text { in }}
$$

The comparison of measured $\left(\mathrm{PFD}_{\mathrm{m}-\mathrm{Sin}}\right)$ and calculated $\left(\mathrm{PFD}_{\mathrm{cs}-\mathrm{in}}\right)$ photon flux density was plotted in Figure 5 . An excellent correlation $(\mathrm{R}>0.89, \mathrm{P}<0.01)$ was highlighted at all investigated positions. Difference between average values of calculated $\left(338 \mu \mathrm{mol} \mathrm{m}^{-2} \mathrm{~s}^{-1}\right)$ and measured $\left(361 \mu \mathrm{mol} \mathrm{m}^{-2} \mathrm{~s}^{-1}\right)$ PFD over the entire period was almost the $6.3 \%$.

Over the long period it was possible to demonstrate a good capability of the numerical model to predict the shading effect inside a photovoltaic greenhouse combining the daily calculated exposed percentage with measurements of solar radiation in PAR range.

But what happen inside the photovoltaic greenhouse during the day? At this aim hourly calculations were performed. Two consecutive days (May $10^{\text {th }}$ and $11^{\text {th }}$ ) characterised by clear sky conditions were chosen as representative days and average hourly analysis of the measured and calculated photon flux density were performed.

Measured values showed how the photon flux density increased until 11.00 a.m., it remained almost constant till 03.00 p.m. and finally decreased. The measured exposed percentage had a parabolic distribution during the day with the minimum at midday and demonstrated the influence of diffuse component of the sun radiation.

Based on previous results, the Ecotect ${ }^{\circledR}$ PVG model was tested by means of an ex post analysis: the PFD was simulated over the entire period inside the PVG and results were finally compared with those measured.

The simulated photon flux density was calculated according to Eq. (2):

$$
P F D_{S-i}=E P_{c-i}\left[4.6 \mu \frac{D S R}{\left(H_{S}-2\right) 3600}\right]
$$

where: PFD $_{s-i}$ is the simulated average daily flux of photons $\left(\mu \mathrm{mol} \mathrm{m}{ }^{-2}\right.$ $\mathrm{s}^{-1}$ ) at position $i ; \mathrm{EP}_{\mathrm{c}-\mathrm{i}}$ is the daily average values of exposed percentage at position $i ; 4.6$ is the value of the conversion factor $\left(1 \mathrm{~W} \mathrm{~m}^{-2} \approx 4.6\right.$ $\mu \mathrm{mol} \mathrm{m} \mathrm{m}^{-2} \mathrm{~s}^{-1}$ ) assuming a flat spectral distribution curve of the source over the $400-700 \mathrm{~nm}$ range (McCree, 1972); $\mu$ is the ratio of the PAR component with respect to the global solar radiation, according to Jacovides et al. (2009), $\mu=0.48$ was assumed; DSR is the daily value of the solar radiation $\left(\mathrm{J} \mathrm{m}^{-2}\right) ; \mathrm{H}_{\mathrm{s}}(\mathrm{h})$ is the duration of sun light in a day,

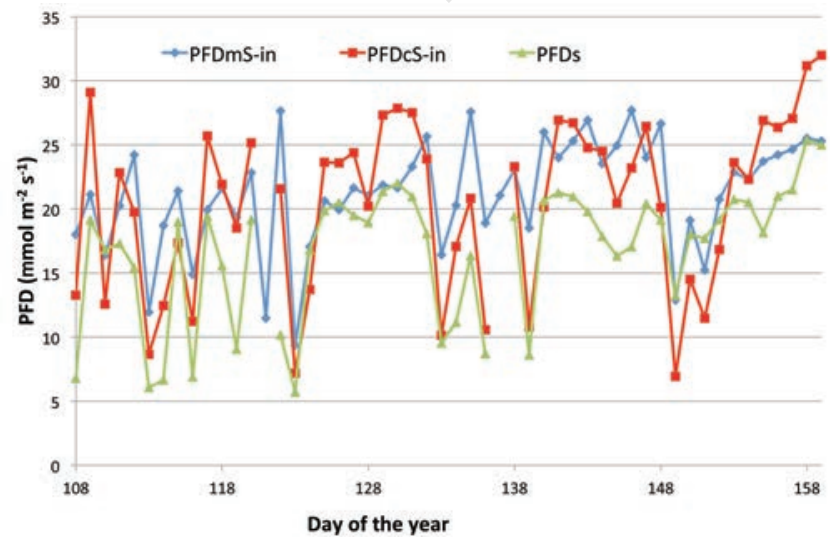

Figure 5. Measured $\left(\mathrm{PFD}_{\mathrm{m}}\right)$, calculated $\left(\mathrm{PFD}_{\mathrm{c}}\right)$ and simulated $\left(\mathrm{PFD}_{\mathrm{s}}\right)$ photon flux density at the position of sensor Sin during the entire investigated period. a corrected value $\left(\mathrm{H}_{\mathrm{s}}-2\right)$ was assumed in order neglect the hours near sunrise and sunset; 3600 is the conversion factor $\mathrm{h} / \mathrm{s}(1 \mathrm{~h}=3600 \mathrm{~s})$.

Data concerning DSR and $\mathrm{H}_{s}$ were gathered at the nearby Meteorological Station of the Airport of Grottaglie (Taranto, Italy) over a period from the $18^{\text {th }}$ April 2014 to the $8^{\text {th }}$ June 2014 .

The comparison of simulated $\left(\mathrm{PFD}_{\mathrm{s}}\right)$ and measured $\left(\mathrm{PFD}_{\mathrm{m}-\mathrm{Sin}}\right)$ photon flux density at the position of the sensor inside the greenhouse was plotted in Figure 5. A very good correlation $(\mathrm{R}>0.78, \mathrm{P}=0.017)$ was highlighted at all investigated positions. The difference between the average values of simulated $\left(16.8 \mu \mathrm{mol} \mathrm{m}{ }^{-2} \mathrm{~s}^{-1}\right)$ and measured (15.5 $\mu \mathrm{mol} \mathrm{m}{ }^{-2} \mathrm{~s}^{-1}$ ) PFD was $7.5 \%$.

In order to better appreciate the variation over space and time of the PAR radiation inside the photovoltaic greenhouse, maps of the PFD distribution were plotted at 8.00 a.m., 12.00 a.m., 06.00 p.m., on the $10^{\text {th }}$ May (Figure 6). May the $10^{\text {th }}$ was chosen as representative day since, basing on meteorological data of the investigated period, only three consecutive days were characterised by clear sky conditions: may the $9^{\text {th }}, 10^{\text {th }}$ and $11^{\text {th }}$. Diagrams showed high fluctuation of PFD values and consequently that the average value of the PFD was not representative of the PAR variation inside the photovoltaic greenhouse (Figure 6).

At 8.00 the highest values of simulated PFD were gathered at the eastern side of the PVG. At 12.00 a.m. - when the sun is almost perpendicular to the roof- highest values were observed around side walls, except for northern wall - and under the two zones not covered by the panels. At 04.00 p.m. due to the sun position, highest values were recorded on the western side of the greenhouse.

Measured values (Figure 7) showed that shaded zones were characterised by very low values of the exposed percentage and such values were mainly due to the diffuse component of the sun radiation. Numerical analysis was able to describe the qualitative variation but not quantified with sufficient precision such low values; indeed, for instance at 12.00 (Figure 7B) shaded zones presented PFD values very close to zero.

\section{Conclusions}

The amount of solar radiation, in the PAR range, falling inside a photovoltaic greenhouse is a very important parameter in order to define agronomic performances expected by the system plant-greenhouse.

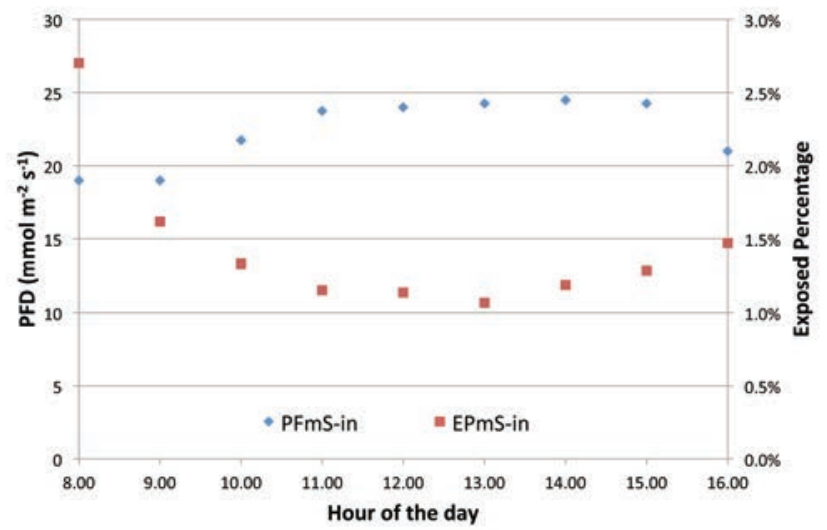

Figure 6. Daily variation of measured photon flux density $\left(\mathrm{PFD}_{\mathrm{m}}\right)$ and exposed percentage $\left(\mathrm{EP}_{\mathrm{mS}-\mathrm{in}}\right)$. 
In this study, calculated and measured photon flux daily values inside a photovoltaic greenhouse over a long period, from $18^{\text {th }}$ April 2014 to $8^{\text {th }}$ June 2014 were compared. Commercial software Autodesk ${ }^{\circledR}$ Ecotect ${ }^{\circledR}$ Analysis was used to calculate the exposed percentage values for the investigated greenhouse model: the calculated photon flux density was obtained multiplying the exposed percentage for the photon flux density measured outside the greenhouse.

The long-term analysis demonstrated a good capability of the numerical model to predict the shading effect inside a photovoltaic greenhouse combining the daily calculated exposed percentage with measurements of solar radiation in PAR range. Difference between average values of calculated (338 $\left.\mu \mathrm{mol} \mathrm{m}^{-2} \mathrm{~s}^{-1}\right)$ and measured $\left(361 \mu \mathrm{mol} \mathrm{m}{ }^{-2} \mathbf{s}^{-1}\right)$ PFD over the entire period was almost the $6.3 \%$. Hourly analysis of the measured and calculated photon flux density were also performed in clear sky conditions, at this aim the hourly average values of two consecutive clear days were used.

Hourly analyses showed that shaded zones were characterised by very low values of the exposed percentage and such values were mainly due to the diffuse component of the sun radiation. Numerical analysis was able to describe the qualitative variation but not quantified with sufficient precision such low values; indeed, for instance at 12.00 shaded zones presented PFD values very close to zero.

For agronomic purposes is strategic to predict the variation over time and space of the PAR radiation inside the greenhouse due to presence of photovoltaic panels. Results demonstrate that the expected reduction of the solar radiation inside the greenhouse could be estimated by a correlation with the percentage of $\mathrm{PV}$ panels on the covering but daily average values do not take into account the fluctuation of the investigated parameters during the day which can be very strong. For this reason more agronomic experiments are necessary to evaluate yield and quality production of vegetables grown in greenhouses covered with PV modules.

Commercial software like Autodesk ${ }^{\circledR}$ Ecotect $^{\circledR}$ is able, with appropriate input values and by correlating results with radiation measurements, to predict with a good accuracy both the average values and the daily fluctuation of solar radiation.

A

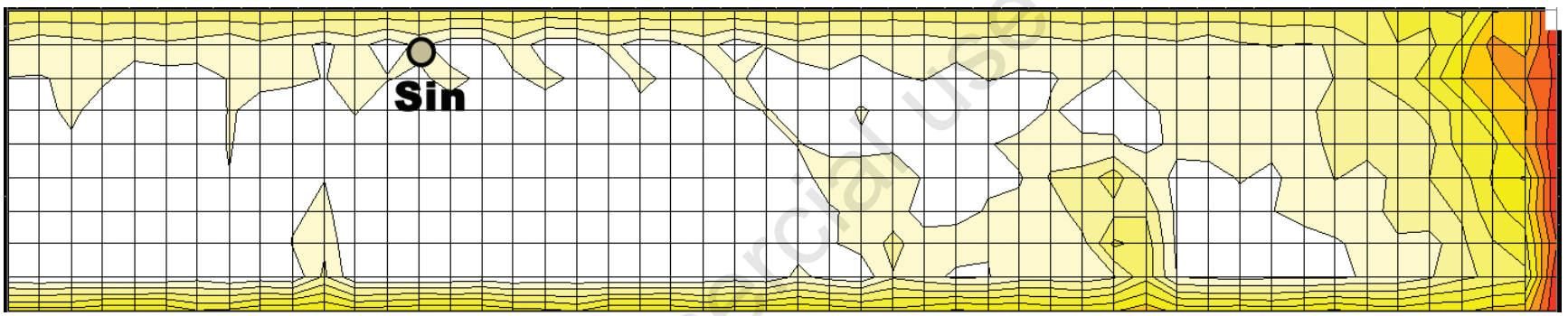

B

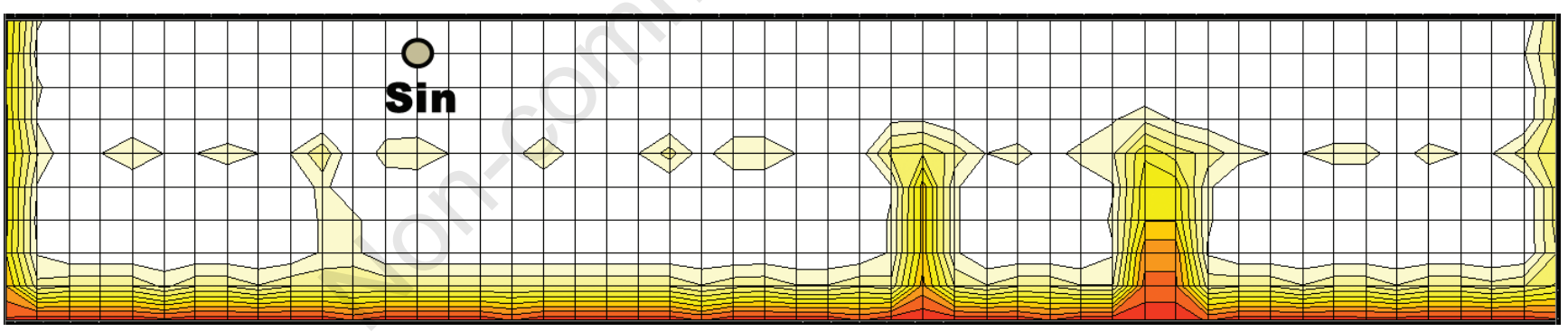

C

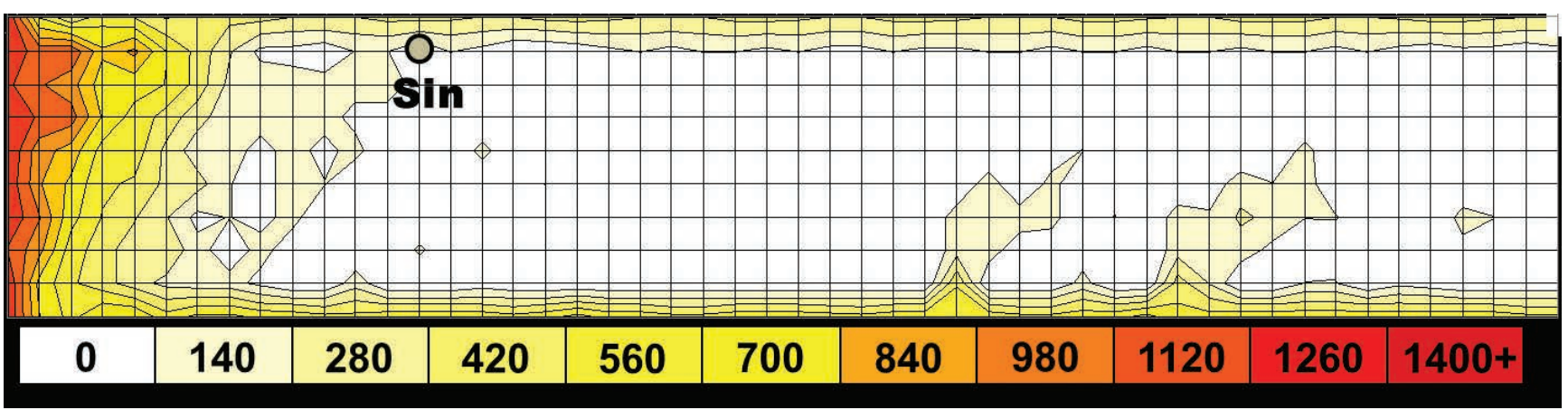

Figure 7. Simulated photon flux density $\left(\mu \mathrm{mol} \mathrm{m} \mathrm{m}^{-2} \mathrm{~s}^{-1}\right)$ inside the photovoltaic greenhouse over a plane parallel to the ground at $1.60 \mathrm{~m}$ from the floor at (A) 8.00 a.m., (B) 12.00 a.m., (C) 04.00 p.m., on the $10^{\text {th }}$ May. 


\section{References}

Al-Ibrahim A., Al-Abbadi N., Al-Helal I. 2006. PV greenhouse system e system description, performance and lesson learned. Acta Hortic. 710:251-64.

Autodesk, Inc. 2011. Autodesk Ecotect Analysis. User reference manual. Available from: http:/usa.autodesk.com/ecotect-analysis/

Badcock J., Lenzen M. 2010. Subsidies for electricity-generating technologies: a review. Ener. Policy 38:5038-47.

Beylot A., Payet J., Puech C., Adra N., Jacquin P., Blanc I., Beloin-SaintPierre D. 2011. Environmental impacts of large-scale grid-connected ground-mounted PV installations. In: B. Moshfegh (ed.), World Renweble Energy Congress - Sweden, 8-13 may 2011, Linkoping, Sweden. Linkoping Electronic Conference Proceedings, 57. Linkoping University Electronic Press, Linkoping, Sweden. Available from: http//www.ep.liu.se/ecp/057/vol11/ecp057vol11.pdf

Biancardo M., Taira K., Kogo N., Kikuchi H., Kumagai N., Kuratani N., Inagawa I., Imoto S., Nakata J. 2007. Characterization of microspherical semi-transparent solar cells and modules. Solar Energy. 81:711-6.

Bojacá C.R., Gil R., Cooman A. 2009. Use of geostatistical and crop growth modeling to assess the variability of greenhouse tomato yield caused by spatial temperature variations. Comput. Electron. Agric. 65:219-27.

British Standards Institution. 2001. BS EN 13031-1:2001. Greenhouses. Design and construction. Commercial production greenhouses; 06 April 2002. British Standards Institution (BSI), London, UK.

Castellano S. 2014. Photovoltaic greenhouses: evaluation of shading effect and its influence on agricultural performances. J. Agric. Engine. XLV:168-75.

Cossu M., Murgia L., Ledda L., Deligios P.A., Sirigu A., Chessa F., Pazzona A. 2014. Solar radiation distribution inside a greenhouse with southoriented photovoltaic roofs and effects on crop productivity. Appl. Ener. 133:89-100.

Dupraz C., Marrou H., Talbot G., Dufour L., Nogier A., Ferard Y., 2011. Combining solar photovoltaic panels and food crops for optimising land use: towards new agrivoltaic schemes. Renew. Energy Generat. Appl. 36:2725-32.

Ecotectect. 2014. Archive site for Autodesk Ecotect Analysis educational resources, notes and tutorials. Available from: http:/wiki.naturalfrequency.com/files/wiki/daylight/design-sky.swf

Emmott J.M.C., Röhr A.J., Campoy-Quiles M., Kirchartz T., Urbina A., Ekins-Daukes N.J., Nelson J. 2015. Organic photovoltaic greenhouses: a unique application for semi-transparent PV?. Energy Environ. Sci. 8:1317-28

EPIA (European Photovoltaic Industries Association). 2014. Global market outlook for photovoltaics 2014-2018. Available from: http//www. epia.org/news/publications/ Accessed: May 2014.

GSE (Gestore Servizi Energetici). 2013. Rapporto statistico fotovoltaico. Available from: http:/www.gse.it/it/Conto\%20Energia/Risultati\% 20incentivazione/Pages/default.aspx Accessed: April 2014 [in Italian].

Gaastra P. 1959. Photosynthesis of crop plants as influenced by light, carbon dioxide, temperature, and stomatal diffusion resistance. Meded. LandbHoogesch. Wageningen 59:1-68.

Gupta R., Tiwari G.N., Kumar A., Gupta Y. 2012. Calculation of total solar fraction for different orientation of greenhouse using 3D-shadow analysis in Auto-CAD. J. En. Build. 47:27-34.

Hornik K. 2015. The R FAQ Frequently asked questions on R - Version 3.2.2015-11-07. Available from: http://CRAN.R-project.org/doc/FAQ/RFAQ.html

Jacovides C.P., Tymvios F.S., Asimakopoulos D.N., Kaltsounides N.A., Theoharatos G.A., Tsitouri M. 2009. Solar global UVB (280-315 nm) and UVA (315-380 $\mathrm{nm}$ ) radiant fluxes and their relationships with broadband global radiant flux at an eastern Mediterranean site. Agric.
Forest Meteorol. 149:1188-200.

Kadowaki M., Yano A., Ishizu F., Tanaka T., Noda S. 2012. Effects of greenhouse photovoltaic array shading on Welsh onion growth. Biosyst. Engine. 111:290-7.

Klaring H.-P., Krumbein A. 2013. The effect of constraining the intensity of solar radiation on the photosynthesis, growth, yield and product quality of tomato. J. Agron. Crop Sci. 199:351-9.

Lopez-Marin J., Galvez A., Gonzalez A., Egea-Gilabert C., Fernandez J.A. 2012. Effect of shade on yield, quality and photosynthesis-related parameters of sweet pepper plants. Acta Hortic. 956:545-52.

Marucci A., Gusman A., Pagniello B., Cappuccini A. 2013. Limits and prospects of photovoltaic covers in Mediterranean greenhouses. J. Agric. Engine. XLIV:1-8.

McCree K.J. 1972. Test of current definitions of photosynthetically active radiation against leaf photosynthesis data. Agric. Meteorol. 10:443-53.

Poncet C., Muller M.M., Brun R., Fatnassi H. 2012. Photovoltaic greenhouses, non-sense or a real opportunity for the greenhouse systems?. Acta Hort. 927:75-9.

Sarasa-Maestro C.J., Dufo-López R., Bernal-Agustín J.L. 2013. Photovoltaic remuneration policies in the European Union. Ener. Policy 55: 317-28.

Schettini E., De Salvador F.R., Scarascia-Mugnozza G., Vox G. 2011. Radiometric properties of photoselective and photoluminescent greenhouse plastic films and their effects on peach and cherry tree growth. J. Hortic. Sci. Biotechnol. 86:79-83.

Sonneveld P.J., Swinkels G.L.A.M., Campen J., van Tuijl B.A.J., Janssen H.J.J., Bot G.P.A. 2010. Performance results of a solar greenhouse combining electrical and thermal energy production. Biosyst. Engine. 106:48-57.

Taylor R. 2014. The potential ecological impacts of ground-mounted photovoltaic solar panels in the UK. Available from: Taylor R. 2014. The potential ecological impacts of ground-mounted pho- tovoltaic solar panels in the UK. Available from: http//www.bsg-ecology.com/wp-content/uploads/2015/01/Solar-panels-and-wildlife-review_RT_FINAL_ 140109.pdf

Tudisca S., Di Trapani A.M., Sgroi F., Testa R., Squatrito R. 2013. Assessment of Italian energy policy through the study of a photovoltaic investment on greenhouse. Afr. J. Agric. Res. 8:3089-96.

Urena-Sanchez R., Callejon-Ferre A.J., Perez-Alonso J., Carreno-Ortega A. 2012. Greenhouse tomato production with electricity generation by roof-mounted flexible solar panels. Sci. Agric. 69:233-9.

U.S. Department of Energy. 2015. Weather data for Italy. Available from: http:/apps1.eere.energy.gov/buildings/energyplus/cfm/weather_data3. cfm/region=6_europe_wmo_region_6/country=ITA/cname=Italy\#inst ructions

Wenger E., Teitel M. 2012. Design of a concentrated photovoltaic system for application in high tunnels. Acta Hortic. 952:401-8.

Yano A., Furue A., Kadowaki M., Tanaka T., Hiraki E., Miyamoto M., Ishizu F., Noda S. 2009. Electrical energy generated by photovoltaic modules mounted inside the roof of a north-south oriented greenhouse. Biosyst. Engine. 103:228-38.

Yano A., Kadowaki M., Furue A., Tamaki N., Tanaka T., Hiraki E., Kato Y., Ishizu F., Noda S. 2010. Shading and electrical features of a photovoltaic array mounted inside the roof of an east-west oriented greenhouse. Biosyst. Engine. 106:367-77.

Yano A., Onoe M., Nakata J. 2014. Prototype semi-transparent photovoltaic modules for greenhouse roof applications. Biosyst. Engine. 122:62-73.

Vox G., Schettini E., Lisi Cervone A., Anifantis A. 2008. Solar thermal collectors for greenhouse heating. Acta Hortic. 801:787-94.

Vox G., Teitel M., Pardossi A., Minuto A., Tinivella F., Schettini E. 2010. Chapter 1: Sustainable greenhouse systems. In: A. Salazar and I. Rios (eds.), Sustainable agriculture: technology, planning and management. Nova Science Publishers, Inc., NY, USA, pp 1-79. 